\title{
Perspektif Konsumen terhadap Pemasaran Paket MICE pada Departemen Pemasaran Hotel Aston Madiun
}

\author{
Priscila Triviana Dewi \\ Program Studi Pariwisata, Fakultas Ilmu Budaya, Universitas Gadjah Mada \\ Email: priscilaatd@gmail.com
}

\begin{abstract}
This study discusses the consumer perspective about the marketing activities of MICE packages organised by the Sales and Marketing Department at Aston Madiun Hotel and Conference Center. The component of organising marketing activities to be evaluated refers to the Marketing Mix model developed by Kotler (2014) knows as 4Ps (product, price, promotion, and place). In this study, researchers used quantitative and qualitative data. Data collection is done by distributing questionnaires to 112 respondents determined through purposive sampling, namely visitors who have purchased MICE packages at Aston Madiun Hotel and Conference Center. Data collection was also obtained from interviews with guests and the Sales and Marketing Department as organisers of hotel marketing activities, observation and literature. In order to formulate the overall evaluation steps, an analysis of the four sectors of hotel marketing activities was carried out in the form of analysis, planning, implementation, and evaluation whose results will be described descriptively. The results showed that the overall marketing mix component received a positive response from guests who had purchased the MICE package at the Aston Madiun Hotel. Two questionnaire items obtain quite low scores, namely hotel items routinely offer and update the details of MICE packages directly to companies and hotels utilising all print media for marketing MICE package activities. The data obtained from the study will be used as study material to evaluate the marketing activities of the Marketing Department in marketing an Aston Madiun Hotel service product, in the form of accuracy of analysis, product development that is in line with the main potential of the hotel, implementation of targeted market segmentation and always evaluating every marketing process that has been passed.
\end{abstract}

Keywords: hotels, marketing activities, MICE Packages, marketing mix, perspective, evaluation

\section{Pendahuluan}

Pariwisata merupakan industri yang menjadi bagian dari hospitality industry. Hospitality industry menawarkan pengalaman dan berfokus dalam memberikan pelayanan dan kepuasan terhadap kebutuhan konsumen. Hospitality industry berhasil menjadi salah satu industri terbesar yang berkembang sangat pesat didunia bahkan kini telah berhasil menjadi industri terbesar kedua di Amerika Serikat (Kotler, 2014:10).

Hotel menjadi salah satu industri yang bergerak dalam hospitality industry. Sebagai jenis akomodasi yang mempergunakan bangunan untuk menyediakan jasa penginapan, makanan dan minuman bagi umum yang dikelola secara komersil (Sujatno, 2008:27), hotel telah berkembang menjadi industri jasa yang menjadi salah satu penopang utama dalam pembangunan pariwisata negeri.

Keberlangsungan hidup sebuah hotel di daerah tertentu tergantung oleh adanya tamu. Bahkan, tamu menjadi pusat perhatian dari hotel dan memiliki kedudukan tertinggi dalam sebuah 
industri (Kotler, 2014:5). Jika produsen dapat memenuhi setiap kebutuhan dari konsumen sebagai tamu, maka keuntungan akan datang dengan sendirinya (Kotler, 2014:6). Oleh karena itu, hotel rutin melakukan penawaran demi dapat memperoleh capaian okupansi hunian melampaui target awal.

Persaingan antarhotel yang kian menjamur di Kota Madiun dan kegiatan MICE yang giat digencarkan oleh berbagai kalangan instansi membuat Hotel Aston Madiun mengembangkan beberapa strategi pemasaran berupa penyediaan paket-paket yang bergerak di bidang MICE sebagai salah satu potensi utama Hotel Aston Madiun dalam upaya meningkatkan jumlah tamu yang menggunakan jasa hotel melalui promo makanan dan minuman, kamar, maupun promosi melalui penyelenggaraan perhelatan terkait.

Meeting, Incentive, Conference, dan Exhibition (MICE) merupakan kegiatan pertemuan, konvensi, perjalanan insentif serta pameran sebagai usaha untuk memberikan jasa pelayanan bagi suatu pertemuan sekelompok orang untuk masalah yang berkaitan dengan kepentingan bersama (Abdullah, 2009). Kegiatan MICE telah menjadi bagian dari paket utama yang ditawarkan oleh Hotel Aston Madiun kepada setiap tamu yang datang.

Pemasaran pariwisata merupakan sebuah sistem yang harus dilaksanakan sebagai kebijaksanaan bagi perusahaan-perusahaan yang bergerak di bidang kepariwisataan baik itu di lingkup lokal, regional, nasional, maupun internasional dilaksanakan untuk mencapai kepuasan yang optimal atas kebutuhan wisatawan di samping untuk memperoleh keuntungan yang wajar (Yoeti, 1980:30).

Departemen Pemasaran (Sales Marketing Department) menjadi sebuah departemen dalam hotel yang memiliki responbilitas untuk mengatur segala sesuatu tentang penyelenggaraan kegiatan pemasaran hotel serta penyediaan paket-paket MICE pada hotel kepada setiap konsumen. Industri MICE, sebagai sebuah sektor pariwisata yang memiliki fokus sasaran massa menjadi strategi utama Hotel Aston Madiun dalam upaya pengenalan hotel ke masyarakat luas serta mendatangkan tamu dalam jumlah yang signifikan.

\section{Kerangka Teori}

Pemasaran merupakan sebuah proses manajerial dan sosial yang mempertemukan kebutuhan dan keinginan dengan membuat dan menambahkan produk baru, serta nilai yang terkandung di dalamnya. Menurut Kotler (2014:11), sebagai sebuah usaha pemenuhan kebutuhan dan kepuasan dari konsumen, kegiatan pemasaran akan lebih mudah dijalankan bila terdapat upaya yang efisien dari sebuah perusahaan untuk meningkatkan kualitas jasa dan pelayanannya, baik itu dalam proses penentuan harga, distribusi, serta strategi promosi yang baik.

\section{Gambar 1}

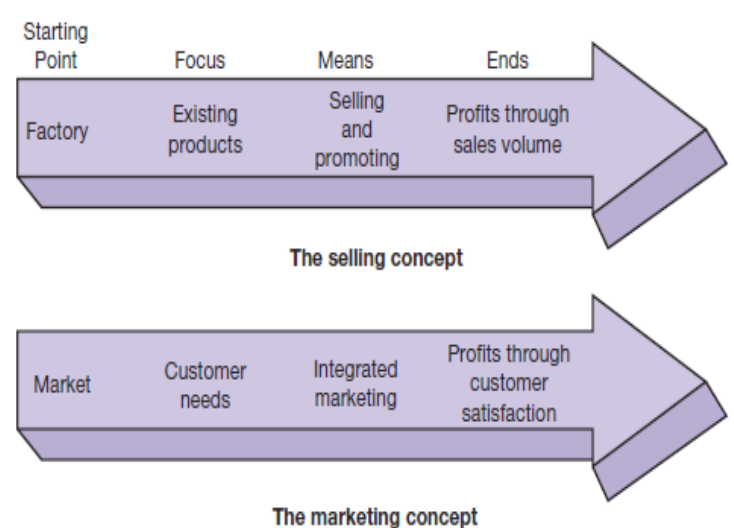

Gambar 1 di atas menjelaskan tentang konsep pemasaran hospitality industry berbeda dengan konsep penjualan pada umumnya. Konsep penjualan pada umumnya berfokus pada barang yang ada untuk kemudian dijual dan memperoleh pembeli dalam jumlah yang banyak. Sedangkan konsep pemasaran dalam hospitality industry berorientasi kepada pemenuhan kebutuhan konsumen yang berupa: (1) keinginan (needs), kebutuhan (wants) dan permintaan (demands); (2) penawaran pemasaran (marketing offerings) berupa produk nyata (tangible products), pelayanan (services), dan pengalaman (experiences); (3) nilai (value) dan kepuasan (satisfaction); (4) pertukaran (exchanges) dan relasi (relationship); dan (5) pasar (markets), tentang pembeli potensial yang kebutuhannya dipenuhi dengan keberadaan penawaran dari industri terkait (Kotler, 2014:17) 
hingga pada akhirnya mencapai kepuasan konsumen yang telah melakukan pembelian pelayanan dan jasa.

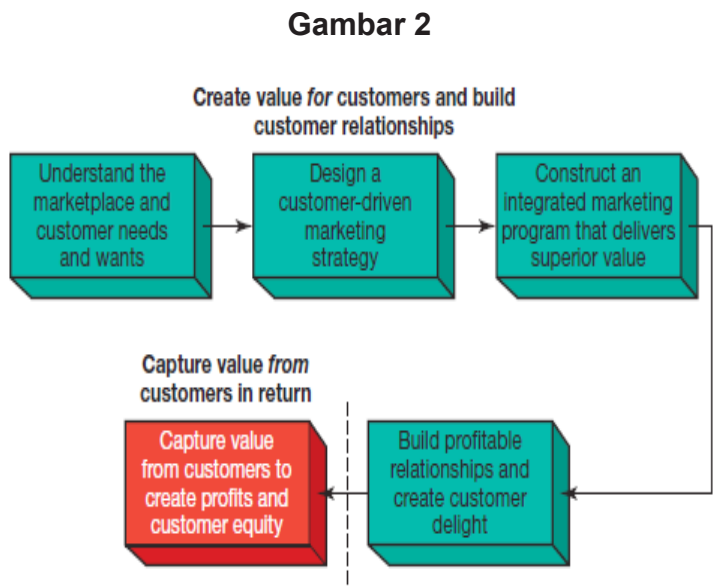

Konsep pemasaran pada hospitality industry tersebut didukung dengan keberadaan dari skema proses pemasaran yang dijelaskan pada Gambar 2 tentang usaha setiap pelaku industri pariwisata dalam kaitannya melahirkan sebuah strategi pemasaran dan membangun sebuah penyelenggaraan kegiatan pemasaran yang mengupayakan nilai jasa yang berkualitas. Skema Proses Pemasaran oleh Kotler (2014:11) ini menjelaskan bahwa saat sebuah industri telah memahami kebutuhan dan keinginan dari segmentasi pasarnya, ia akan berupaya untuk bisa menyelenggarakan strategi pemasaran kualitas terbaik kepada konsumennya. Hotel menjadi salah satu industri yang memiliki strategi pemasaran guna memenuhi kebutuhan setiap tamu yang datang. Sebagai subjek utama yang bertugas untuk memenuhi setiap kebutuhan dan pelayanan kepada tamu, sudah selayaknya bila sebuah manajemen hotel melahirkan penawaran-penawaran berbagai jenis paket yang diselenggarakan sebagai perwujudan dari konsep pemasaran yang dilandaskan atas kebutuhan konsumen.

Gambar 3 menjelaskan konsep pemasaran era modern dapat diselenggarakan oleh sebuah industri saat strategi pemasaran dapat terlaksana dengan baik kepada setiap segmen pasar yang ada. Bauran pemasaran (Marketing Mix) tersebut terbagi menjadi 4 bagian yaitu produk, harga, tempat, serta promosi. Program pemasaran yang efektif memadukan keempat elemen bauran pemasaran

\section{Gambar 3}

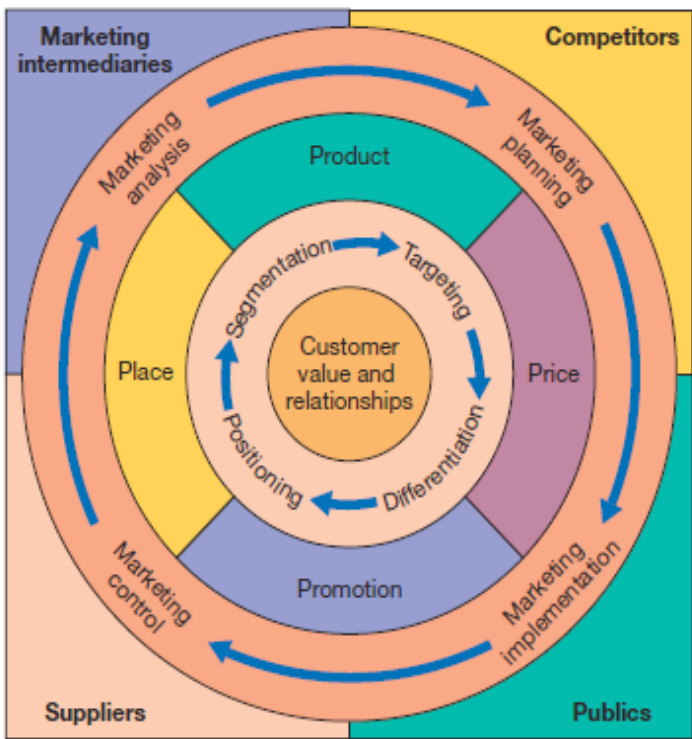

untuk dapat mencapai tujuan pemasaran serta memberikan nilai yang berkesan kepada setiap konsumen.

Departemen Pemasaran menjadi sebuah departemen di sebuah industri perhotelan yang berperan untuk mengidentifikasi kebutuhan dari setiap konsumen yang dikembangkan melalui konsep bauran pemasaran (Kotler, 2014). Saat segmentasi pasar hotel sudah tersusun dengan sistematis, maka Departemen Pemasaran kemudian melahirkan penawaran sesuai dengan potensi utama hotel kepada setiap target kegiatan pemasaran.

MICE sebagai wisata konvensi berupa Meeting, Incentive, Conference serta Event telah menarik atensi dari beberapa industri perhotelan dalam negeri, termasuk Hotel Aston Madiun. Penyelenggaraan kegiatan pemasaran paket MICE oleh Hotel Aston Madiun telah mempertimbangkan beberapa faktor berkaitan dengan potensi utama hotel maupun segmentasi pasar yang ada di wilayah Kota Madiun dan sekitarnya. Guna dapat mempertahankan kualitas pelayanan dan jasa serta mengembangkannya menjadi suatu hal yang lebih baik, Hotel Aston Madiun perlu melakukan sebuah evaluasi terhadap setiap pelayanan yang sudah diselenggarakan selama periode waktu tertentu.

Gambar 4 menjelaskan tentang proses analisis perencanaan strategi pemasaran yang 


\section{Gambar 4}

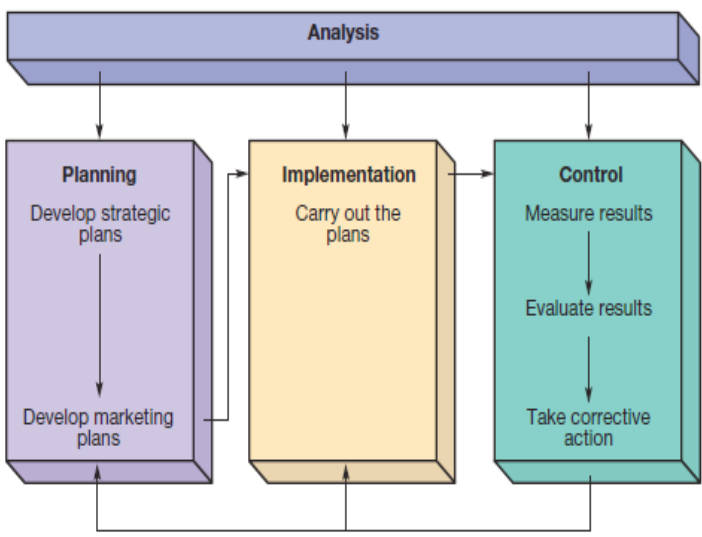

matang kemudian melahirkan proses implementasi. Implementasi setiap perencanaan kegiatan pemasaran yang telah dibuat kepada konsumen tersebut memerlukan kontrol untuk dapat mengevaluasi serta mengambil respon terhadap perbaikan produk yang sudah ada.

Peneltian diharapkan mampu menarik kesimpulan secara menyeluruh tentang peran Departemen Pemasaran dalam melakukan kegiatan pemasaran paket MICE di Kora Madiun. Departemen Pemasaran juga diharapkan mampu melahirkan keberlanjutan produk serta melakukan evaluasi dan mengetahui perspektif konsumen terhadap aktivitas pemasaran paket MICE oleh Hotel Aston Madiun mulai dari tahap analisis dan perencanaan hingga masa pelaksanaan sehingga dapat menjadi bahan evaluasi dari pihak pengelola hotel untuk bisa lebih meningkatkan performa hotel khususnya dalam bidang pemasaran hotel kepada setiap pengunjung.

\section{Metode Penelitian}

Penelitian ini menggunakan pendekatan deskriptif kuantitatif. Metode pengumpulan data diawali dengan melakukan studi literatur melalui perpustakaan dan media digital guna mempelajari buku maupun penelitian terdahulu berkenaan dengan kegiatan pemasaran di industri perhotelan serta penyelenggaraan MICE di Kota Madiun.

Wawancara kepada Departemen Pemasaran Hotel Aston Madiun juga dilakukan guna memperoleh data valid berkaitan dengan penyelenggaraan kegiatan pemasaran paket MICE oleh Departemen Pemasaran hotel. Kegiatan wawancara ditujukan kepada narasumber Department of Sales Manager, Public Relation Officer, Sales Executive, dan Executive Secretary, ketua perhelatan Corporate Gathering dan ketua perhelatan Wedding Exhibition.

Survei berupa sebaran kuesioner kepada setiap pengunjung yang telah melakukan pembelian paket MICE di Hotel Aston Madiun selama periode 2018 dilakukan guna menunjang data penelitian. Masing-masing indikator pertanyaan dikembangkan dari keberadaan Teori Bauran Pemasaran (4P) berupa Produk (Product), Harga (Price), Promosi (Promotion) dan Distribusi (Place).

Teknik pengambilan sampel dilakukan secara sengaja (purposive sampling) (Sugiyono, 2014:122). Sampel respondennya ditentukan dari jumlah konsumen yang telah melakukan pembelian paket MICE di Hotel Aston Madiun berupa ruang meeting, ballroom, atau turut serta dalam event Wedding Exhibition dan Corporate Gathering pada tahun 2018 yaitu sejumlah 402 perusahaan maupun instansi. Jumlah sampel responden ditentukan dengan menggunakan perhitungan formula sebagai berikut (Slovin dalam Kusmayadi dan Sugiarto, 2000:74).

$$
n=\frac{N}{1+N(e)^{2}}
$$

Margin error yang digunakan dalam penelitian adalah $8 \%$. Maka jumlah sampel yang diambil adalah sejumlah 112 responden dengan penjabaran perhitungan sampel sebagai berikut:

$$
n=\frac{N}{1+N(e)^{2}}
$$

$$
\begin{gathered}
n=\frac{402}{1+402(8 \%)^{2}} \\
n=\frac{402}{1+402(0.0064)} \\
n=\frac{402}{1+2.5728} \\
n=\frac{402}{3.5728} \\
n=112
\end{gathered}
$$


Bentuk pertanyaan yang diajukan kepada konsumen dalam sebaran kuesioner disajikan dalam bentuk tertutup, sehingga responden hanya perlu memberi lingkaran pada angka yang telah disediakan. Terdapat empat angka yang tersedia, yaitu angka 4,3,2,1. Responden akan melingkari angka 4 bila sangat setuju, 3 bila setuju, 2 bila tidak setuju, dan 1 bila sangat tidak setuju. Penggunaan metode Rating Scale ini menghasilkan data mentah yang berupa angka yang kemudian ditafsirkan dalam pengertian kualitatif.

Observasi dilakukan dengan cara melakukan pengamatan secara langsung mengenai penyelenggaraan paket MICE Hotel Aston Madiun. Sebagai pengamat independen, peneliti bertugas untuk mencatat, menganalisis, dan memperoleh informasi nyata mengenai penyelenggaraan kegiatan pemasaran hotel. Observasi difokuskan pada perhelatan Wedding Exhibition dan Corporate Gathering, serta penjualan paket meeting dan ballroom kepada tamu.

Pengolahan dan analisis data dilakukan setelah seluruh kuesioner dijawab secara lengkap oleh responden. Data kuesioner kemudian dihitung dan diolah menggunakan Microsoft Excel hingga menghasilkan rata-rata hasil data.

\begin{tabular}{|c|c|c|}
\hline No. & Respon & Skor \\
\hline 1. & Bila Sangat Tidak Setuju & 1 \\
\hline 2. & Bila Kurang Setuju & 2 \\
\hline 3. & Bila Cukup Setuju & 3 \\
\hline 4. & Bila Sangat Setuju & 4 \\
\hline
\end{tabular}

Sumber: Sugiyono (2015:122)

Masing-masing item kuesioner dikelompokkan pada variabel Bauran Pemasaran yang berupa produk (product), harga (price), promosi (promotion), dan tempat atau distribusi (place). Seluruh item kuesioner akan dicari nilai rata-ratanya hingga kemudian dapat dilakukan analisis terhadap keseluruhan rata-rata setiap item kuesioner yang ada.

Nilai rata-rata dari masing-masing item kuesioner dihitung dengan menggunakan rumus sebagai berikut (Sutrisno, 2015:46):

$$
\mathrm{M}=\frac{\Sigma f X}{N}
$$

\section{Keterangan:}

$$
\begin{array}{ll}
\mathrm{M} & =\text { mean (rata-rata) } \\
\Sigma f X & =\text { frekuensi } \\
\mathrm{N} & =\text { nilai data }
\end{array}
$$

Setelah mengetahui nilai rata-rata dari masing-masing item kuesioner, maka akan dicari lebar interval guna dapat melahirkan tafsiran dari nilai rata-rata. Lebar interval tersebut ditentukan melalui rumus sebagai berikut (Sutrisno, 2015:17):

$$
\begin{gathered}
\mathrm{I}=\frac{\text { jarak pengukuran }(R)}{\text { jumlah interval }} \\
\mathrm{I}=\frac{4-1}{4}=\frac{3}{4}=0.75
\end{gathered}
$$

Hasil dari lebar interval dengan nilai 0.75 digunakan untuk melahirkan tafsiran nilai rata-rata seperti yang tertera pada tabel 1.2. Keberadaan dari tafsiran digunakan untuk melakukan analisis secara deskriptif berkenaan dengan nilai rata-rata dari setiap item kuesioner yang ada.

\begin{tabular}{|c|c|}
\hline Nilai Rata-Rata & Kategori \\
\hline $1.00-1.75$ & Sangat Tidak Baik \\
\hline $1.76-2.50$ & Tidak Baik \\
\hline $2.51-3.25$ & Cukup Baik \\
\hline $3.26-4.00$ & Sangat Baik \\
\hline
\end{tabular}

Sumber: Analisis Peneliti, 2019

Dalam kaitan melahirkan penilaian akhir terhadap kinerja pemasaran paket MICE Departemen Pemasaran Hotel Aston Madiun, telah diberikan item tambahan pada bagian akhir kuesioner. Penilaian akhir terdiri atas empat kategori yaitu 4 (sangat baik), 3 (cukup baik), 2 tidak baik) dan 1 (sangat tidak baik). Responden diminta mengisi salah satu dari empat pilihan kategori tersebut guna menghasilkan kesimpulan akhir yang akan dinarasikan secara deskriptif kualitatif hingga kemudian melahirkan rumusan evaluasi serta perspektif konsumen terhadap penyelenggaraan kegiatan pemasaran paket MICE Hotel Aston Madiun. 


\section{Hasil dan Pembahasan}

\subsection{Lingkup Kerja Departemen Pemasaran Hotel Aston Madiun}

Departemen Pemasaran Hotel Aston Madiun dipimpin oleh seorang Department of Sales Manager (DOSM) yang membawahi beberapa karyawan yang berperan sebagai Sales Executive (SE), Graphic Desain Officer (GDO), Public Relation Officer (PRO), serta Sales Admin. Departemen Pemasaran ini memiliki fokus pembagian tugas antar anggota departemen terhadap masing-masing segmentasi pasar yang ada.

\subsubsection{Peran Sales Executive (SE) dalam Kegiatan Pemasaran}

Sales Executive (SE) berperan dalam menjalin relasi dengan perusahaan. Saat hospitality industry menjadi sebuah industri yang unik karena menganggap karyawan sebagai sebuah produk yang juga dijual kepada konsumen (Kotler, 2014:288), sehingga setiap hal yang dilakukan oleh karyawan saat berhadapan langsung dengan tamu adalah hal representatif dari hotel yang bersangkutan. Oleh karena itu, keberadaan dari pengelompokan maupun pembagian tugas antar Sales Executive (SE) Departemen Pemasaran membuat setiap karyawan dapat lebih mempersiapkan diri sebagai seorang hotelier guna dapat mencapai kepuasan dari segmentasi pasarnya masing-masing. Di sisi lain, ada sebuah hal yang membuat pengelompokan kerja Sales Executive (SE) menjadi kurang efisien.

Hal-hal antisipasi perlu dilakukan oleh Departemen Pemasaran mengingat bahwa fokus kegiatan pemasaran Hotel Aston Madiun adalah customer oriented. Konsisten dalam menjaga komunikasi dengan setiap konsumen, manajemen waktudan mencatat detail seluruh penyelenggaraan acara menjadi beberapa upaya yang dapat dilakukan Sales Executive (SE) guna kesalahan dan mencapai kepuasan setiap konsumen yang ada.

\subsubsection{Sales Call sebagai Media Promosi}

Sales Call merupakan agenda rutin yang dilakukan oleh Sales Executive (SE) Hotel Aston Madiun dengan mendatangi beberapa perusahaan guna melakukan promosi hotel kepada konsumen. Rutinitas penawaran tersebut dilakukan dengan cara melakukan kegiatan Sales Call pada setiap hari kerja aktif. Kegiatan Sales Call, menjadi sebuah relevansi bahwa rutinitas dalam membangun komunikasi dan relasi yang baik dengan konsumen melalui kegiatan-kegiatan promosi aktif menjadi sebuah hal yang tidak kalah penting untuk dapat diupayakan dan diselenggarakan oleh hotel.

\subsubsection{Sales Blitzing sebagai Media Promosi}

Sales Blitzing merupakan kegiatan mendatangi dan mengajak berbagai vendor berupa perusahaan untuk turut serta dalam memeriahkan penyelenggaraan acara. Kegiatan ini menjadi sebuah strategi pemasaran yang inovatif oleh Hotel Aston Madiun saat menjelang penyelenggaraan perhelatan dalam skala besar guna dapat meraih atensi dari setiap instansi menjadi sebuah dasar konsistensi hotel dalam proses penyelenggaraan acara dari awal hingga akhir terselenggaranya perhelatan.

\subsubsection{Talkshow dan Iklan sebagai Media Promosi}

Kegiatan talkshow dan pemasangan iklan dirilis di radio maupun di beberapa media cetak. Seluruh kegiatan tersebut dapat diupayakan secara rutin dan oleh karena kerjasama yang telah disepakati oleh Hotel Aston Madiun dengan beberapa media siar maupun media cetak. Public Relation Officer (PRO) bertanggungjawab dalam menjalin relasi dan mengatur kerjasama antar hotel dengan setiap media siar maupun cetak.

Perkembangan teknologi komunikasi dan informasi yang pesat membuat Hotel Aston Madiun memiliki lebih banyak kesempatan untuk melakukan promosi sehingga Hotel Aston Madiun dapat membangun relasi maupun kerjasama yang lebih kuat lagi dengan beberapa media siar maupun media cetak lain dan tidak hanya menetap pada relasi dengan media-media yang sudah dijalin sekarang ini.

\subsubsection{Konvoi sebagai Media Promosi}

Kegiatan konvoi diselenggarakan saat menjelang beberapa kegiatan besar hotel seperti New Year's Eve maupun Wedding Exhibition. Kegiatan berupa konvoi keliling kota dengan memakai pakaian khusus (dresscode) dan menggunakan iringan tertentu oleh staf hotel guna memperoleh perhatian masyarakat luas dan juga melakukan penyebaran kertas informasi event Jogja. 
Sebagai sebuah media promosi rutin hotel, sistematika konvoi, baik itu mengenai tema yang akan diangkat saat melakukan konvoi, maupun keselamatan staf yang terlibat dalam kegiatan serta masyarakat sekitar yang menyaksikan kegiatan konvoi oleh hotel perlu diperhatikan. Selalu melakukan koordinasi dengan kepolisian setempat serta memberikan detail rute perjalanan konvoi menjadi sebuah kewajiban yang harus dilakukan oleh hotel guna memperlancar berlangsungnya kegiatan promosi ini dari tahun ke tahun.

\subsubsection{Pemasangan Baliho sebagai Media Promosi}

Baliho, merupakan media alternatif dan informatif oleh Hotel Aston Madiun dalam melakukan penyebaran informasi acara maupun paket-paket terbaru hotel kepada masyarakat di wilayah Kota Madiun dan sekitarnya. Baliho akan diganti secara berkala sesuai dengan kontrak pemasangan yang telah disepakati antara pihak hotel dengan vendor periklanan (advertising).

Seperti yang telah diketahui bahwa tujuan utama bergerak di industri pariwisata ialah untuk dapat menyelenggarakan sebuah industri yang dapat melahirkan kepuasan konsumen dan mengelolanya dengan baik sehingga setiap harapan akan kebutuhan konsumen terpenuhi (Kotler, 2014:7), maka sudah menjadi kewajiban bagi Departemen Pemasaran Hotel Aston Madiun sebagai industri dengan customer oriented. Seluruh komponen pemasaran yang telah diupayakan oleh Hotel Aston sejak awal melibatkan diri dalam hospitality industry di Kota Madiun menjadi hal yang harus dijaga konsistensinya. Perihal mencapai kepuasan konsumen mengenai pelayanan dan jasa hotel, melahirkan produk-produk baru sesuai dengan keunggulan yang dimiliki oleh hotel, serta melakukan evaluasi terhadap setiap kegiatan pemasaran serta paket-paket MICE hotel yang telah dirilis pada periode waktu sebelumnya menjadi beberapa rutinitas yang perlu digencarkan.

\subsection{Evaluasi Kegiatan Pemasaran Paket MICE Departemen Pemasaran Hotel Aston Madiun}

Penyelenggaraan sebuah kegiatan pemasaran produk oleh hotel perlu memperhatikan kaidah bauran pemasaran yang berlaku dalam hospitality industry. Bauran pemasaran $4 \mathrm{P}$ berupa tempat atau distribusi (place), harga (price), produk (product), dan yang terakhir promosi (promotion) menjadi 4 pilar utama yang memperoleh atensi dari Hotel Aston Madiun untuk melahirkan sebuah pelayanan dan jasa hotel dan memperhatikan setiap kebutuhan, keinginan dan harapan oleh tamu sebagai pembeli jasa. Guna menghasilkan evaluasi terhadap kegiatan pemasaran paket MICE oleh Departemen Pemasaran Hotel Aston Madiun, maka telah dilakukan sebaran kuesioner kepada setiap tamu yang pernah melakukan pembelian jasa hotel baik itu berupa sewa ruang meeting, ballroom, menyelenggarakan event maupun mengikuti beberapa event yang diadakan oleh Hotel Aston Madiun.

Pada bagian ini disajikan data hasil kuesioner yang telah disebarkan dan diisi oleh sekitar 112 responden dengan margin error 8\% (delapan persen) terhadap 4 sektor bauran pemasaran.

\subsubsection{Evaluasi Bauran Pemasaran: Tempat (Place)}

Pada tabel 4.1 di bawah menunjukan tentang hasil evaluasi dan atau penilaian oleh responden yang pernah melakukan pembelian paket MICE di Hotel Aston Madiun. Dari 35 item kuesioner yang diajukan kepada konsumen tersebut, item nomor 1-10 mengulas tentang tempat atau distribusi (Place) yang menjadi bagian dari bauran pemasaran hotel.

\begin{tabular}{|c|c|c|c|c|c|c|}
\hline \multirow{2}{*}{ No. } & \multirow{2}{*}{ Indikator } & \multicolumn{4}{|c|}{ Persentase (\%) Jawaban } & \multirow{2}{*}{$\begin{array}{l}\text { Rata- } \\
\text { Rata }\end{array}$} \\
\hline & & SS & $\mathbf{S}$ & TS & STS & \\
\hline 1 & Lokasi hotel strategis & 41 & 59 & 9 & 3 & 3.23 \\
\hline 2 & Tempat parkir hotel luas & 35 & 58 & 18 & 1 & 3.13 \\
\hline 3 & $\begin{array}{l}\text { Kenyamanan tamu menjadi prioritas } \\
\text { utama hotel }\end{array}$ & 64 & 44 & 3 & 1 & 3.52 \\
\hline 4 & Tata ruang hotel rapi dan detail & 73 & 37 & 1 & 1 & 3.63 \\
\hline 5 & $\begin{array}{l}\text { Hotel memiliki kualitas keamanan } \\
\text { yang terjamin }\end{array}$ & 57 & 47 & 6 & 2 & 3.42 \\
\hline 6 & $\begin{array}{l}\text { Kualitas kebersihan hotel sangat } \\
\text { terjaga }\end{array}$ & 69 & 38 & 3 & 2 & 3.55 \\
\hline 8 & $\begin{array}{l}\text { Lokasi hotel mudah dijangkau oleh } \\
\text { pengunjung }\end{array}$ & 58 & 46 & 8 & 0 & 3.45 \\
\hline 7 & Aksesibilitas menuju hotel mudah & 55 & 48 & 8 & 1 & 3.40 \\
\hline 9 & Resepsionis hotel ramah & 47 & 62 & 2 & 1 & 3.38 \\
\hline 10 & $\begin{array}{l}\text { Hotel memiliki petunjuk arah } \\
\text { (guideline) event yang informatif }\end{array}$ & 35 & 59 & 17 & 1 & 3.14 \\
\hline & $\begin{array}{l}\text { ategori Penilaian 1-4: } \\
00-1,75=\text { Sangat Tidak Baik } \\
76-2,50=\text { Kurang Baik }\end{array}$ & & 3,2 & $\mathrm{Cl}$ & Baik & \\
\hline
\end{tabular}

Data di atas menyebutkan bahwa pada bauran pemasaran hotel yang meliputi tempat atau distribusi (place), "tata ruang hotel yang rapi dan detail" memperoleh apresiasi tertinggi oleh responden yang pernah melakukan pembelian jasa dengan nilai rata-rata sebesar 3.63.

Selain itu, item kuesioner tentang "kualitas 
kebersihan hotel sangat terjaga" juga memperoleh apresiasi oleh responden dengan nilai rata-rata sebesar 3.55 setelah aspek tata ruang hotel yang rapi dan detail. Berdasarkan Kotler (2014:110) dalam buku Marketing for Hospitality and Tourism, tempat atau distribusi (place) merupakan seluruh kegiatan maupun aktivitas hotel yang diselenggarakan secara nyata guna memunuhi target konsumen yang tersedia. Sehingga, hasil penilaian tentang fasilitas maupun tata ruang hotel yang rapi dan detail serta kualitas kebersihan hotel yang terjaga menunjukan bahwa Hotel Aston Madiun selalu mengupayakan kenyamanan dari setiap tamu yang datang. Responsibilitas untuk dapat memenangkan hati para konsumen serta menjadikan konsumen sebagai prioritas utama menjadi hal sederhana dapat diupayakan oleh hotel guna membangun citra yang baik di hadapan konsumen yang membeli jasa.

Item kuesioner "hotel memiliki tempat parkir yang luas" memperoleh nilai terendah dengan total nilai rata-rata sebesar 3.13. Meski telah didukung oleh berbagai macam fasilitas yang diselenggarakan guna memenuhi kebutuhan dari setiap konsumen yang datang, keberadaan dari tempat parkir yang luas menjadi kebutuhan utama dari hotel saat sedang digunakan untuk menyelenggarakan perhelatan dan konverensi dengan skala besar.

\subsubsection{Evaluasi Bauran Pemasaran: Harga (Price)}

Pada tabel 4.2 di bawah menunjukan tentang penilaian yang diberikan oleh konsumen terhadap sektor harga (price) dari bauran pemasaran paket MICE Hotel Aston Madiun. Item nomor 11-15 pada kuesioner membahas tentang segala sesuatu yang meliputi penjualan paket MICE, baik itu harga paket maupun strategi promosi harga oleh manajemen hotel.

\begin{tabular}{|c|c|c|c|c|c|c|}
\hline \multirow{2}{*}{ No. } & \multirow{2}{*}{ Indikator } & \multicolumn{4}{|c|}{ Persentase (\%) Jawaban } & \multirow{2}{*}{$\begin{array}{l}\text { Rata- } \\
\text { Rata }\end{array}$} \\
\hline & & SS & $\mathbf{S}$ & TS & STS & \\
\hline 11 & $\begin{array}{l}\text { Harga paket sesuai dengan kualitas } \\
\text { produk dan pelayanan yang diterima } \\
\text { konsumen }\end{array}$ & 35 & 66 & 11 & 0 & 3.21 \\
\hline 12 & $\begin{array}{l}\text { Hotel memiliki penawaran khusus } \\
\text { (special price) kepada konsumen } \\
\text { yang telah melakukan pembelian } \\
\text { paket lebih dari satu kali }\end{array}$ & 35 & 59 & 16 & 2 & 3.13 \\
\hline 13 & $\begin{array}{l}\text { Penawaran paket MICE sesuai } \\
\text { dengan kebutuhan konsumen }\end{array}$ & 33 & 68 & 9 & 2 & 3.18 \\
\hline 14 & $\begin{array}{l}\text { Kemudahan proses administrasi } \\
\text { pasca event berlangsung }\end{array}$ & 49 & 53 & 9 & 1 & 3.34 \\
\hline 15 & $\begin{array}{l}\text { Harga dan penawaran lebih menarik } \\
\text { dibanding hotel lain }\end{array}$ & 34 & 54 & 23 & 1 & 3.08 \\
\hline \multicolumn{7}{|c|}{ *Kategori Penilaian 1-4: } \\
\hline & $0-1,75=$ Sangat Tidak Baik & \multirow{2}{*}{\multicolumn{5}{|c|}{$2,51-3,25=$ Cukup Baik }} \\
\hline \multicolumn{2}{|c|}{$1,76-2,50=$ Kurang Baik } & & & & \multicolumn{2}{|c|}{$3,26-4,00=$ Sangat Baik } \\
\hline
\end{tabular}

Item kuesioner tentang "kemudahan proses administrasi pasca event berlangsung" memperoleh apresiasi tertinggi konsumen yang pernah melakukan pembelian jasa hotel dengan rata-rata nilai sebesar 3.34 dengan kategori nilai sangat baik. Sebagai hotel yang memiliki relasi yang erat dengan setiap pelanggannya, kepercayaan antar konsumen dan penyedia jasa menjadi kunci utama berlangsungnya sebuah kegiatan baik itu dalam skala kecil maupun besar. Hotel Aston Madiun, menggunakan sistem DP sebelum acara dan akan dilunasi oleh konsumen saat acara yang bersangkutan telah berakhir. Di samping itu, item kuesioner tentang "harga paket sesuai dengan kualitas produk dan pelayanan yang diterima konsumen" juga memperoleh nilai ratarata tertinggi dari konsumen sebesar 3.21.

Harga, sebagai sebuah hal yang harus dibayarkan oleh konsumen karena telah memperoleh jasa dan pelayanan hotel (Kotler, 2014:110), menjadi hal yang harus diperhatikan oleh hotel sebagai penyedia jasa serta konsumen sebagai penerima jasa. Penentuan harga yang tepat sasaran melalui analisis terhadap segmen pasar yang ada, membuat kegiatan pemasaran menjadi lebih tepat guna, baik itu menguntungkanbagi pihak hotel karena memperoleh segementasi pasar yang tepat, juga menguntungkan bagi pihak konsumen sebagai pembeli jasa karena memperoleh produk yang terbaik dengan harga yang sesuai.

\subsubsection{Evaluasi Bauran Pemasaran: Produk (Product)}

Tabel 4.3 menunjukkan penilaian yang diberikan oleh konsumen meliputi keseluruhan produk (product) yang ditawarkan oleh Departemen Pemasaran Hotel Aston Madiun kepada setiap tamu yang datang. Item kuesioner tentang "kepuasan tamu menjadi prioritas utama hotel" memperoleh penilaian tertinggi dari konsumen dengan rata-rata nilai sebesar3.56. Di sisi lain, item kuesioner tentang "tingkat higienitas makanan hotel yang terjamin" memperoleh nilai rata-rata tertinggi dengan capaian sebesar 3.52. Hal tersebut selaras dengan konsep pelayanan pada hospitality industry bahwa setiap pelaku industri pariwisata harus mengedepankan pelayanan terbaik untuk melahirkan kepuasan dari setiap tamu yang datang dan melakukan pembelian jasa. 


\begin{tabular}{|c|c|c|c|c|c|c|}
\hline \multirow{2}{*}{ No. } & \multirow{2}{*}{ Indikator } & \multicolumn{4}{|c|}{ Persentase (\%) Jawaban } & \multirow{2}{*}{$\begin{array}{l}\text { Rata- } \\
\text { Rata }\end{array}$} \\
\hline & & SS & $\mathbf{S}$ & TS & STS & \\
\hline 16 & $\begin{array}{l}\text { Fasilitas ruang pertemuan maupun } \\
\text { ballroom sangat menunjang kegiatan } \\
\text { rapat atau pertemuan pelanggan }\end{array}$ & 64 & 41 & 6 & 1 & 3.5 \\
\hline 17 & $\begin{array}{l}\text { Konsumen mudah memperoleh } \\
\text { informasi tentang produk MICE hotel }\end{array}$ & 37 & 57 & 16 & 2 & 3.15 \\
\hline 18 & $\begin{array}{l}\text { Ballroom maupun ruang pertemuan } \\
\text { dilengkapi dengan fasilitas-fasilitas } \\
\text { yang berfungsi secara optimal }\end{array}$ & 45 & 58 & 8 & 1 & 3.31 \\
\hline 19 & Kualitas produk MICE hotel bersaing & 40 & 66 & 5 & 1 & 3.29 \\
\hline 20 & Pelayanan hotel berkualitas & 63 & 45 & 3 & 1 & 3.51 \\
\hline 21 & Sarana dan prasarana hotel lengkap & 62 & 45 & 4 & 1 & 3.5 \\
\hline 22 & $\begin{array}{l}\text { Hotel memiliki responbilitas yang } \\
\text { tinggi terhadap seluruh permintaan } \\
\text { konsumen }\end{array}$ & 49 & 55 & 7 & 1 & 3.36 \\
\hline 23 & $\begin{array}{l}\text { Kepuasan tamu menjadi prioritas } \\
\text { utama hotel }\end{array}$ & 66 & 43 & 3 & 0 & 3.56 \\
\hline 24 & $\begin{array}{l}\text { Hotel menjalin relasi yang baik } \\
\text { dengan konsumen }\end{array}$ & 61 & 43 & 8 & 0 & 3.47 \\
\hline 25 & $\begin{array}{l}\text { Tingkat higienitas makanan hotel } \\
\text { terjamin }\end{array}$ & 61 & 48 & 3 & 0 & 3.52 \\
\hline 26 & $\begin{array}{l}\text { Hotel meminimalisir kesalahan } \\
\text { selama event berlangsung }\end{array}$ & 45 & 58 & 8 & 1 & 3.31 \\
\hline 27 & $\begin{array}{l}\text { Hotel menjaga privasi dan } \\
\text { kenyamanan konsumen selama event } \\
\text { berlangsung }\end{array}$ & 59 & 46 & 7 & 0 & 3.46 \\
\hline 28 & $\begin{array}{l}\text { Hotel menjaga komunikasi yang baik } \\
\text { dengan konsumen setelah event } \\
\text { berlangsung }\end{array}$ & 58 & 49 & 5 & 0 & 3.47 \\
\hline $\begin{array}{l}{ }^{*} \mathrm{Ka} \\
1,0 \\
1,7\end{array}$ & $\begin{array}{l}\text { tegori Penilaian 1-4: } \\
-1,75=\text { Sangat Tidak Baik } \\
-2,50=\text { Kurang Baik }\end{array}$ & $\begin{array}{l}2,51 \\
3,26\end{array}$ & & & & \\
\hline
\end{tabular}

Item kuesioner tentang "kualitas produk MICE yang bersaing" memperoleh skor total terendah bila dibandingkan dengan item kuesioner yang lain, yaitu sekitar 3.29. Meski masih dalam rentang kategori sangat baik, beberapa hal perlu diperhatikan oleh Hotel Aston Madiun sebagai penyedia jasa. Persaingan industri pariwisata yang cukup ketat di wilayah Kota Madiun mendongkrak giat pemasaran hotel untuk lebih kreatif lagi dalam menyediakan pelayanan dan jasa guna lebih menarik atensi masyarakat luas. Rutin dalam melakukan kilas balik (review) dan kegiatan memantau (monitoring) setiap strategi pemasaran yang telah dilakukan (Kotler, 2014: 116) membuat sebuah hotel yang bergerak dalam hospitality industry semakin peka terhadap kebutuhan yang diperlukan olehkonsumen yang ada.

\subsubsection{Evaluasi Bauran Pemasaran: Promosi (Promotion)}

Pada tabel 4.4 di bawah menunjukkan tentang hasil penilaian dari konsumen maupun tamu yang pernah melakukan pembelian paket terhadap komponen promosi (promotion) yang telah dilakukan oleh Hotel Aston Madiun dalam rangka melakukan kegiatan pemasaran paket MICE yang dimiliki oleh hotel.

Item kuesioner tentang "hotel memiliki beragam promosi paket MICE yang persuasif"

\begin{tabular}{|c|l|c|c|c|c|c|c|}
\hline \multirow{2}{*}{ No. } & \multirow{2}{*}{ Indikator } & \multicolumn{4}{|c|}{ Persentase (\%) Jawaban } & \multirow{2}{*}{$\begin{array}{l}\text { Rata- } \\
\text { Rata }\end{array}$} \\
\cline { 2 - 6 } 29 & $\begin{array}{l}\text { Flyer (brosur) paket MICE hotel } \\
\text { Aston Madiun informatif }\end{array}$ & 35 & 63 & 14 & 0 & 3.19 \\
\hline 30 & $\begin{array}{l}\text { Hotel memiliki beragam promosi } \\
\text { paket MICE yang persuasif }\end{array}$ & 40 & 64 & 8 & 0 & 3.29 \\
\hline 31 & $\begin{array}{l}\text { Hotel mempergunakan sosial media } \\
\text { sebagai media promosi secara efektif }\end{array}$ & 35 & 63 & 12 & 2 & 3.17 \\
\hline 32 & $\begin{array}{l}\text { Hotel rutin melakukan penawaran } \\
\text { dan update detail paket MICE secara } \\
\text { langsung (walk-in) ke perusahaan- } \\
\text { perusahaan }\end{array}$ & 25 & 60 & 26 & 1 & 2.97 \\
\hline 33 & $\begin{array}{l}\text { Hotel memanfaatkan seluruh media } \\
\text { cetak untuk kegiatan pemasaran } \\
\text { paket MICE }\end{array}$ & 26 & 60 & 25 & 1 & 2.99 \\
\hline 34 & $\begin{array}{l}\text { Hotel memasang baliho dan spanduk } \\
\text { promosi di spot-spot yang strategis }\end{array}$ & 36 & 49 & 24 & 3 & 3.05 \\
\hline 35 & $\begin{array}{l}\text { Hotel cepat tanggap dalam merespon } \\
\text { pertanyaan konsumen terkait paket } \\
\text { MICE }\end{array}$ & 41 & 59 & 11 & 1 & 3.25 \\
\hline
\end{tabular}

"Kategori Penilaian 1-4:

$1,00-1,75=$ Sangat Tidak Baik $\quad 2,51-3,25=$ Cukup Baik

$1,76-2,50=$ Kurang Baik $\quad 3,26-4,00=$ Sangat Baik

memperoleh atensi yang cukup tinggi dari konsumen dengan rata-rata nilai sebesar 3.29 dan atau masuk dalam kategori yang sangat baik. Hal tersebut mendukung pernyataan bahwa Hotel Aston Madiun sebagai pelaku jasa menyediakan sarana promosi yang persuasif yang bersifat menyeluruh hingga dapat memperoleh atensi khusus dari setiap pembeli jasa.

Penilaian tentang responsibilitas hotel dijawab pada item kuesioner "hotel cepat tanggap dalam merespon pertanyaan konsumen terkait paket MICE" yang memperoleh nilai rata-rata sebesar 3.25. Penilaian tersebut menjadi capaian yang cukup baik dari hotel mengingat industri pelayanan dan jasa rawan terhadap komplain yang diajukan oleh konsumen terkait dengan kualitas jasa yang telah mereka terima.

Konsistensi kegiatan Sales Call sebagai salah satu media komunikasi hotel dalam melakukan promosi kepada setiap perusahaan maupun instansi yang ada. Item kuesioner tentang "hotel rutin melakukan penawaran dan update detail paket MICE secara langsung (walk-in) ke perusahaanperusahaan" memperoleh nilai rata-rata sebesar 2.97 yang berarti cukup baik namun perlu ditingkatkan lagi. Dengan semakin meningkatkan rutinitas penyelenggaraan kegiatan Sales Call, diharapkan mampu membangun komunikasi yang baik antar perusahaan maupun instansi sehingga tercipta revisit intention maupun pembelian berulang yang dilakukan oleh setiap instansi maupun perusahaan yang ada. 


\subsection{Penilaian Kegiatan Pemasaran Departemen Pemasaran Hotel Aston Madiun secara Keseluruhan}

Berdasarkan hasil penilaian yang telah diberikan oleh seluruh responden yang pernah menggunakan jasa Hotel Aston Madiun, baik itu berupa sewa ruang meeting, ballroom, maupun menyelenggarakan dan atau mengikuti kegiatan di Aston Madiun, dapat dihitung nilai rata-rata kegiatan pemasaran Paket MICE oleh Departemen Pemasaran Hotel Aston Madiun dari keseluruhan penilaian yang telah diberikan. Penentuan nilai rata-rata dari masingmasing item kuesioner tersebut diperoleh dengan cara membagi frekuensi kuesioner dengan nilai data.

Namun, guna mengambil kesimpulan akhir dari penelitan terkait dengan "Perspektif Konsumen terhadap Pemasaran Paket MICE Departemen Pemasaran Hotel Aston Madiun", maka penulis menambahkan satu item kuesioner sebagai item penutup guna dapat menyimpulkan penilaian umum dari masing-masing responden terhadap keseluruhan kinerja pemasaran maupun setiap fasilitas pelayanan dan jasa telah diberikan Hotel Aston Madiun, baik itu terhadap paket meeting, ballroom, serta event Wedding Exhibition dan Corporate Gathering.

\begin{tabular}{|l|c|}
\hline \multicolumn{1}{|c|}{ Kategori } & Penilaian (\%) \\
\hline Sangat baik & 72,32 \\
\hline Cukup Baik & 27,68 \\
\hline Tidak Baik & 0 \\
\hline Sangat Tidak Baik & 0 \\
\hline
\end{tabular}

Sumber: Analisis Peneliti, 2019

Capaian penilaian sangat baik oleh 81 responden $(72,32 \%)$ dan perolehan penilaian cukup baik oleh 31 responden $(27,68 \%)$ menjadi prestasi Hotel Aston Madiun dalam membangun citra dan melakukan kegiatan pemasaran selama periode waktu ini. Hal tersebut lantas membuat hotel perlu melakukan evaluasi maupun pengembangan terhadap seluruh penyelenggaraan kegiatan promosi guna dapat meningkatkan pelayanan dan jasa secara lebih baik lagi.

\subsection{Upaya Efisiensi Penyelenggaraan Aktivitas Pemasaran Paket MICE oleh Departemen Pemasaran Hotel Aston Madiun}

Guna mengevaluasi kegiatan pemasaran paket MICE dan dapat menciptakan strategi pemasaran yang menguntungkan kedua belah pihak, baik itu pihak manajemen selaku penyelenggara maupun konsumen selaku pembeli jasa, sebuah perusahaan harus menaruh perhatian khusus terhadap kegiatan manajemennya sendiri (Kotler, 2014:111). Hal tersebut disebabkan karena empat sektor yang terlibat di dalam sebuah manajemen pemasaran yaitu adanya analisis (analysis), perencanaan (planning), implementasi (implementation) dan kontrol (control) saling terkait dan tidak dapat dipisahkan antar satu dengan yang lainnya. Sehingga, keberadaan dari analisis akan menghasilkan sebuah perencanaan yang baik oleh pihak hotel sebagai produsen yang bergerak di industri pariwisata. Perencanaan yang telah dirancang akan diselaraskan dengan potensi utama yang dimiliki hotel hingga kemudian dapat diimplementasikan kepada segmentasi pasar hotel terkait. Implementasi dari produk-produk yang telah dibentuk akan menghasilkan kontrol terhadap kepuasan dan atau respon konsumen sebagai pembeli pelayanan dan jasa. Kontrol terhadap produk-produk yang telah diimplementasikan kepada segmen pasar melahirkan evaluasi terhadap produk pemasaran hotel. Evaluasi ini dimulai dengan cara melakukan peninjauan kembali (review) terhadap produk yang telah disebar kemudian dikembangkan lagi hingga dapat menjadi produk yang lebih baik dari yang sebelumnya.

Pada bagian ini akan dijabarkan empat kegiatan analisis, perencanaan, implementasi serta tahap evaluasi yang dapat diupayakan oleh Hotel Aston Madiun hingga kemudian bisa mencapai sebuah efektivitas penyelenggaraan kegiatan pemasaran paket MICE oleh Departemen Pemasaran Hotel Aston Madiun.

\subsubsection{Analisis terhadap Sektor Pasar dan Potensi Utama Hotel Aston Madiun}

Sebagai industri yang berorientasi kepada kepuasan konsumen sebagai pembeli layanan dan jasa hotel, ketepatan analisis terhadap setiap segmen pasar dan memahami potensi-potensi utama yang dimiliki oleh hotel menjadi beberapa agenda yang wajib diupayakan oleh manajemen hotel khususnya 
Departemen Pemasaran Hotel Aston Madiun guna dapat menyelenggarakan sebuah kegiatan pemasaran hotel yang sesuai dengan kebutuhan konsumen. Analisis terperinci, menjadi salah satu penentu manajemen hotel untuk kemudian dapat memutuskan langkah tepat yang akan diambil hotel dalam penyelenggaraan sebuah industri hospitalitas.

Kota Madiun, merupakan sebuah kota yang berorientasi dalam penyelenggaraan kegiatan perdagangan dan industri. Terdapat perkembangan industri yang melahirkan persaingan antarhotel yang cukup ketat. Hotel Aston Madiun memiliki beberapa analisis yang dikembangkan guna mendukung fungsinya sebagai penyedia jasa, hingga kemudian memutuskan untuk menjadi sebuah industri perhotelan yang bergerak di bidang MICE.

Industri MICE menjadi sebuah fokus industri baru dan berani diangkat oleh Aston Madiun sebagai sebuah hotel berstandar internasional pertama di Kota Madiun. Didukung dengan adanya infrastruktur hotel yang memadahi, disertai dengan tenaga kerja yang ahli di bidangnya, membuat industri MICE Hotel Aston Madiun berkembang dengan pesat.

Fungsi analisis pada dasarnya ada untuk melahirkan pengetahuan yang sistematis dan terperinci mengenai kelebihan, kekurangan, tantangan yang dihadapi hotel serta peluang yang dimiliki oleh hotel dalam keterlibatannya sebagai sebuah penyedia layanan dan jasa di hospitality industry. (Kotler, 2014:111) Sehingga, dalam upaya penyelenggaraan sebuah kegiatan pemasaran yang sesuai dengan harapan konsumen, analisis membuat Hotel Aston Madiun dapat menentukan sikap yang tepat guna mencapai keberhasilan hotel dalam meraih atensi dan kepercayaan dari setiap pengguna jasa di wilayah kota Madiun.

Upaya dalam melahirkan ketepatan analisis hotel dari waktu ke waktu dapat diusahakan melalui beberapa hal. Sebagai sebuah hotel dengan fokus penyelenggaraan paket MICE di wilayah Kota Madiun dan sekitarnya, selalu menjaga konsistensi relasi dengan berbagai macam instansi maupun perusahaan dapat membangun kepekaan hotel terhadap kebutuhan pasar dari periode waktu tertentu. Sehingga, dengan meningkatkan rutinitas dari aktivitas pemasaran hotel berupa Sales Call dan Sales Blitzing, dapat menjadi media Hotel Aston
Madiun dalam upaya memahami ketertarikan dan harapan dari setiap segmentasi pasarnya pada masa itu.

\subsubsection{Perencanaan terhadap Pengembangan Paket MICE dan Strategi Pemasaran Hotel Aston Madiun}

Pada saat menyusun perencanaan terhadap pengembangan hotel sebagai sebuah industri pariwisata, hotel harus memiliki analisis yang tepat terkait dengan segmentasi pasar yang ada dan strategi pemasaran yang akan diambil untuk dapat diterima di segmen pasar tersebut. Hotel Aston Madiun, sebagai salah satu hotel berstandar internasional yang terdapat di Kota Madiun, menetapkan MICE sebagai produk utama yang akan dijual ke segmentasi pasar yang ada.

Dalam menjalankan perannya sebagai hospitality industry yang berfokus terhadap penyelenggaraan kegiatan MICE, Hotel Aston Madiun telah melakukan pengelompokan terhadap potensi-potensi hotel hingga kemudian siap dipasarkan kepada tamu. Paket-paket tersebut antara lain penawaran ruang meeting dari muatan kecil hingga dapat menampung peserta dalam jumlah yang besar, paket menginap dengan ragam pilihan kamar, paket ballroom, ruang outdoor, penyelenggaraan perhelatanoleh Hotel Aston Madiun seperti halnya Wedding Exhibition, New Year's Eve, Corporate Gathering, dan paket makan malam (dinner) pada saat hari raya tertentu.

Pada dasarnya, proses perencanaan menjadi sebuah rangkaian panjang dari pihak manajemen hotel dalam rangka mempersiapkan paket- paket unggulan yang akan diimplementasikan kepada setiap segmentasi pasar yang ada, baik itu mulai dari proses promosi, penjualan, distribusi ke setiap konsumen yang terdiri dari instansi, perusahaan maupun perseorangan hingga kemudian dapat melakukan evaluasi terhadap setiap produk yang sudah terjual.

Sehingga, sebelum melakukan perencanaan dan pengembangan lebih lanjut terkait dengan produk hotel, langkah pertama yang dapat dilakukan oleh hotel guna mendasari proses perencanaan di Hotel Aston Madiun adalah dengan melakukan perbaikan berkala terkait dengan infrastruktur gedung maupun seluruh fasilitas yang terdapat di Hotel Aston Madiun. Memperbaharui seluruh 
infrastruktur hotel secara rutin tanpa harus melupakan visi dan misi penyelenggaraan hotel menjadi beberapa hal yang dapat dipertimbangkan oleh Hotel Aston Madiun sehingga tetap bisa melahirkan persaingan dengan hotel-hotel lain yang terdapat di wilayah Kota Madiun dan sekitarnya.

Di sisi lain, kegiatan perencanaan yang dapat diupayakan ialah dengan menjalin komunikasi yang baik antar pihak hotel dengan konsumen guna mendorong Hotel Aston Madiun dapat selalu termotivasi untuk melakukan pembaharuan terhadap seluruh paket dan jasa yang ditawarkan. Komunikasi dan relasi yang erat juga harus dibangun antar pihak hotel dengan media cetak maupun media penyiaran. Mengingat bahwa promosi merupakan salah satu bagian penting dalam proses penyelenggaraan kegiatan pemasaran hotel, maka ruang lingkup kerjasama Hotel Aston Madiun dengan media cetak maupun penyiaran harus semakin diperluas. Keberadaan dari kerjasama tersebut bertujuan untuk mempermudah hotel dalam kaitannya membangun citra dan pengenalan paket ke masyarakat luas.

\section{Implementasi Paket MICE dan Pelayanan Jasa Hotel Aston Madiun}

Implementasi sebagai proses penerapan perencanaan yang telah dibuat pada setiap segmen pasar yang tersedia menjadi sebuah penentu apakah setiap paket yang telah dilahirkan dalam proses perencanaan dapat diterima dengan baik oleh konsumen dan akan lahir pembelian berulang oleh konsumen di masa yang akan datang. Pada tahun kelima penyelenggaraan industri pariwisata berbasis perhotelan ini, Hotel Aston Madiun semakin memperoleh kepercayaan dari konsumennya untuk kemudian lebih bisa mengembangkan kualitas produk dan jasa yang ada.

Namun, pada tahap pelaksanaan implementasi paket MICE dan pelayanan jasa kepada konsumen, hotel sesekali menjumpai beberapa kendala maupun kesalahpahaman terhadap kebutuhan-kebutuhan yang telah diajukan oleh konsumen. Sehingga, Hotel Aston Madiun sudah seharusnya memiliki beberapa tahapan pelayanan yang siap dilahirkan guna menyesuaikan kebutuhan dari konsumen pada saat hari pelaksanaan acara.

Mengingat bahwa seringkali terdapat beberapa kebutuhan tambahan yang bersifat spontan dan diajukan oleh konsumen, sebagai perusahaan yang bergerak di industri hospitalitas, Hotel Aston Madiun harus mampu mengupayakan setiap permintaan konsumen secara lebih maksimal. Di samping itu, selalu mengusahakan kegiatan komunikasi dua arah antara pihak hotel dan konsumen selama penyelenggaraan acara juga diperlukan guna meminimalisir hal-hal yang dapat merugikan Hotel Aston Madiun sebagai penyedia layanan dan jasa di kemudian hari. Komunikasi dua arah tersebut juga dapat berfungsi sebagai media hotel untuk tetap menjalin relasi yang baik dengan setiap konsumen yang telah melakukan pembelian jasa.

Implementasi sebagai sebuah kegiatan yang berkenaan dengan penjualan setiap produk paket MICE yang telah dirancang oleh Departemen Pemasaran Hotel Aston Madiun kepada segmentasi pasar yang telah ditargetkan pada akhirnya melahirkan kontrol dan evaluasi dari pihak hotel untuk kemudian dapat melahirkan gagasan perancangan dan perencanaan paket produk MICE secara lebih baik lagi.

\section{Kontrol dan Evaluasi Seluruh Aktivitas Pemasaran Paket MICE Hotel Aston Madiun}

Aktivitas pemasaran Hotel Aston Madiun ditutup dengan melakukan kontrol dan evaluasi terhadap produk-produk yang dijual maupun kegiatankegiatan yang telah berlangsung di hotel dalam periode waktu tertentu. Evaluasi terhadap produk maupun penyelenggaraan kegiatan dilangsungkan guna memberikan kepastian bahwa setiap usaha yang telah diupayakan oleh Hotel Aston Madiun, baik itu hal- hal yang bersifat moral pada umumnya dan material pada khususnya dapat tersampaikan dengan baik kepada setiap konsumen maupun segmentasi pasar yang ada.

Berdasarkan hasil sebaran kuesioner kepada responden yang pernah melakukan pembelian produk pelayanan dan jasa di Hotel Aston Madiun, hotel telah memperoleh respon yang positif dari setiap konsumen yang ada. Dari seluruh item kuesioner yang telah disebar dan dikelompokkan menjadi 4 sektor bauran pemasaran, yaitu tempat (place), harga (price), produk (product), dan promosi (promotion); seluruh kelompok bauran pemasaran yang tersedia telah mencapai kategori penilaian yang baik. Dari keseluruhan item kuesioner, hanya terdapat dua item yang 
memperoleh kategori nilai yang cukup rendah, yaitu item "Hotel rutin melakukan penawaran dan update detail paket MICE secara langsung (walk-in) ke perusahaan-perusahaan" dengan nilai rata-rata 2.97 dan juga item terkait "Hotel memanfaatkan seluruh media cetak untuk kegiatan pemasaran paket MICE" dengan nilai rata-rata 2.99. Meski sebenarnya dua item kuesioner tersebut masih termasuk dalam kategori nilai yang cukup baik, akan tetapi manajemen hotel perlu memberikan perhatian khusus terhadap kedua item yang samasama berasal dari bidang promosi (promotion).

Kegiatan promosi oleh Hotel Aston Madiun dapat semakin ditingkatkan menyadari bahwa terdapat persaingan industri di Kota Madiun yang semakin menguat dan segmentasi pasar yang semakin pandai dalam menentukan produk-produk terbaik. Sehingga, dengan semakin ditingkatkannya rutinitas kegiatan Sales Call diharapkan dapat semakin meningkatkan jumlah pembelian produk serta jasa hotel. Di samping itu, Hotel Aston Madiun diharapkan dapat lebih memanfaatkan seluruh sarana media cetak yang ada di Kotta Madiun guna melangsungkan kegiatan pemasaran paket MICE di masa yang akan datang. Keberadaan dari pemasangan iklan yang memuat promosi hotel di berbagai jenis media cetak tersebut juga diharapkan dapat menjadi salah satu media pembentukan nama baik hotel di kalangan masyarakat luas.

Pemberian nilai yang baik oleh sebagian besar responden yang melakukan pengisian kuesioner menjadi sebuah keberhasilan Hotel Aston Madiun dalam menyelenggarakan kegiatan pemasaran paket MICE hotel di wilayah Kota Madiun dan sekitarnya. Hanya saja masih perlu dukungan dan peningkatan kualitas kegiatan pemasaran yang ada untuk dapat lebih menjangkau konsumen dari berbagai jenis kalangan. Ketika sebuah perusahaan yang bergerak dalam industri pariwisata (dalam hal ini industri perhotelan) sudah memahami dengan baik letak kelemahan dari sebuah kegiatan pemasaran paket MICE di hotel, maka yang dapat dilakukan yaitu mulai mengulang dalam proses penyusunan analisis awal, perancangan produk dengan pertimbangan yang ada, melakukan implementasi terhadap setiap hal yang telah dirancang hingga kemudian dapat melahirkan strategi pemasaran yang lebih baik lagi dari yang sebelumnya.

Kegiatan pemasaran, menjadi sebuah kegiatan yang memiliki responbilitas dalam mengidentifikasi dan mempelajari hal-hal terkait dengan kebutuhan konsumen secara lebih mendalam (Kotler, 2014:118). Hingga kemudian, Departemen Pemasaran, menjadi sebuah departemen yang memiliki tanggungjawab dalam menjalankan perannya sebagai pengendali strategi pemasaran lengkap dengan tahap perancangannya.

Sehingga, keberadaan dari Departemen Pemasaran dinilai penting guna menjalin komunikasi dan relasi yang mengikat antar pihak Hotel Aston Madiun dengan setiap konsumen yang ada.

\section{Kesimpulan}

\subsection{Kesimpulan}

Berdasarkan penelitian di lapangan tentang "Perspektif Konsumen terhadap Pemasaran Paket MICE pada Departemen Pemasaran Hotel Aston Madiun" dapat ditarik kesimpulan bahwa Hotel Aston Madiun telah berhasil memperoleh respon dan atau tanggapan positif dari sebagian besar konsumen yang pernah melakukan pembelian produk jasa hotel. Hanya saja, perlu dilakukan beberapa evaluasi dan pengembangan terhadap beberapa strategi pemasaran yang sudah diselenggarakan hotel selama beberapa periode waktu terakhir.

Mengingat bahwa hotel merupakan sebuah industri yang diselenggarakan untuk memenuhi kepuasan konsumen terhadap pelayanan dan jasa, rangkaian kegiatan analisis, perencanaan, implementasi serta evaluasi dapat menjadi media efektif bagi Departemen Pemasaran dalam melakukan kontrol terhadap setiap penyelenggaraan kegiatan pemasaran yang telah dilakukan.

Berdasarkan hasil sebaran kuesioner, penyelenggaraan evaluasi terhadap strategi pemasaran hotel dapat lebih difokuskan terhadap dua item kuesioner dari bauran pemasaran berupa promosi (promotion) yang memperoleh penilaian cukup rendah dari sebagian besar responden. Kedua item tersebut antara lain "Hotel rutin melakukan penawaran dan update detail paket MICE secara langsung (walk-in) ke perusahaan-perusahaan" dengan nilai rata-rata 2.97 dan juga item terkait "Hotel memanfaatkan seluruh media cetak untuk kegiatan pemasaran paket MICE" dengan nilai ratarata 2.99

Peningkatkan rutinitas kegiatan Sales Call 
dapat diupayakan hotel guna semakin membangun relasi dan kepercayaan antar produsen dan konsumen. Di sisi lain, Hotel Aston Madiun juga diharapkan bisa lebih mengoptimalkan manfaat dari seluruh media yang ada di wilayah Kota Madiun dan sekitarnya. Optimalisasi tersebut bisa dimulai dengan cara membuka peluang hotel untuk melakukan kerjasama dengan berbagai jenis media cetak maupun media penyiaran yang baru. Kerjasama maupun relasi yang baru antar hotel dengan berbagai jenis media, membuka peluang untuk semakin memperluas jaringan pemasaran hotel serta dapat menjadi salah satu upaya pembangunan nama baik hotel di kalangan masyarakat umum.

Pada akhirnya, ketepatan analisis yang dihasilkan hotel terhadap setiap kebutuhan dari segmen pasar, pengembangan produk yang sesuai dengan potensi utama hotel, tepat sasaran dalam melakukan implementasi produk, serta selalu melakukan kontrol dan evaluasi terhadap setiap proses pemasaran yang telah dilalui menjadi beberapa upaya yang dapat dilakukan oleh Hotel Aston Madiun guna semakin menunjukan keseriusan untuk dapat menekuni bidang industri pariwisata dalam negeri.

\subsection{Rekomendasi}

Berdasarkan penelitian yang telah dilakukan, berikut merupakan rekomendasi yang dapat diberikan oleh penulis untuk pengembangan hotel dan penelitian selanjutnya:

Departemen Pemasaran, untuk tetap bisa mempertahankan kualitas kinerja yang baik yang telah dicapai sejauh ini. Karena hotel bergerak di bidang industri pariwisata yang bersifat dinamis, maka kontrol serta pembaharuan terhadap seluruh produk maupun paket MICE hotel harus dilakukan secara berkala guna dapat mengikuti perkembangan zaman dan kebutuhan dari setiap konsumen.

Analisis maupun perencanaan terhadap masa depan hotel harus selalu disesuaikan dengan karakteristik yang dimiliki hotel sebagai hospitality industry. Kelebihan Hotel Aston Madiun dalam bidang MICE didukung dengan keberadaan infrastruktur yang memadahi menjadi modal utama hotel dalam melakukan implementasi kepada setiap segmentasi pasar yang ada. Mempertahankan konsistensi pelayanan dan jasa mampu mendongkrak eksistensi hotel di kalangan masyarakatluas. Keberadaan dari tingkat kepercayaan konsumen yang tinggi kepada hotel, diharapkan mampu melahirkan pembelian yang berulang oleh konsumen yang sama hingga bahkan dapat menghadirkan konsumen yang baru, di masa yang akan datang.

Penelitian ini mengkaji teori aktivitas pemasaran Kotler (2014) berupa analisis, perencanaan, implementasi serta kontrol dan evaluasi yang dikombinasi dengan adanya model bauran pemasaran berupa place, price, product, dan promotion sebagai indikator penilaiannya. Bagi penelitian selanjutnya, diharapkan mampu menghasilkan sebuah penelitian yang bersifat lebih mendalam mengenai masing-masing komponen yang ada, baik itu analisis, perencanaan, implementasi atau evaluasi sehingga dapat dijadikan sebagai sebuah referensi pengembangan yang lebih terperinci, terstruktur dan sistematis terhadap kegiatan pemasaran pada hotel.

\section{Daftar Pustaka}

Abdullah, I. A. (2009). Manajemen Konferensi dan Event. Yogyakarta: Gadjah Mada University Press.

Andayani, N. L. H. (2013). Manajemen Pemasaran Pariwisata. Yogyakarta: Graha Ilmu.

Christinasari, S. (2016). Peran Customer Relations dalam Menciptakan Citra Positif bagi Aston Madiun Hotel \& Conference Center. Surakarta: Universitas Negeri Sebelas Maret.

Hadi, S. (2015). Statistik. Yogyakarta: Penerbit Pustaka Pelajar.

Hartono, Y. (2014). Perkembangan Kota Madiun sebagai Kota Gadis Tahun 2000- 2013. Madiun: Jurnal Agastya Vol. 04 No 02 Juli 2014.

Kotler, P. R. (2003). Marketing Insights from A to Z. New Jersey: John Wiley and Sons, Inc.

Kotler, P. R. (2014). Marketing for Hospitality and Tourism. Sixth Edition. United States of America: Pearson International Limited.

Kusmayadi dan Sugiarto, E. (2000). Metodologi Penelitian dalam Bidang Kepariwisataan. Jakarta: PT Gramedia Pustaka Utama.

Prideaux, B. et al. (2006). Managing Tourism and Hospitality Services. North American: CABI International.

Reid, R. D. and Bojanic, D. C. (2006). Hospitality Marketing Management. Fourth Edition. John 
Wiley \& Son, Inc.

Setiyawan, A. D. dan Kusbandono, H. (2018). Sarana dan Prasarana Pendukung Industri MICE. Epicheirisi, 2, 1-6.

Srijani, N. dan Hidayat, A. S. (2017). Pengaruh Fasilitas Terhadap Kepuasan Pelanggan di Aston Madiun Hotel \& Conference Center. Jurnal Penelitian Ilmu Ekonomi WIGA, 7, 31-38.

Sugiyono. (2014). Metode Penelitian Bisnis. Bandung: Penerbit Alfabeta.
Sugiyono. (2015). Metode Penelitian Kuantitatif, Kualitatif, dan $R \& D$. Bandung: Penerbit Alfabeta. Supriyanto, M. dan Taali, M. (2018). Pengaruh Bauran Pemasaran (Marketing Mix) terhadap Pengambilan Keputusan Menginap di The Sun Hotel Madiun. Epicheirisi, 2, 13-21.

Sujatno, B. (2008). Hotel Courtesy. Yogyakarta: Penerbit Andi Yogyakarta.

Yoeti, O. A. (2001). Strategi Pemasaran Hotel. Jakarta: Gramedia Pustaka Utama. 